\title{
PENGARUH PEMBERIAN JAGUNG KUNING FERMENTASI DENGAN SUPLEMENTASI POLYUNSATURATED FATTY ACID (PUFA) DAN L-KARNITIN TERHADAP DAYA TETAS TELUR PUYUH
}

\section{THE EFFECT OF FEEDING FERMENTED YELLOW CORN SUPPLEMENTED POLYUNSATURATED FATTY ACID (PUFA) AND L-CARNITINE ON QUAIL EGG HATCHABILITY}

\author{
Ayu Siswoyo Putri*, Sudibya, dan Ratih Dewanti \\ Jurusan Peternakan, Fakultas Pertanian, Universitas Sebelas Maret, Surakarta, 57126
}

Submitted: 16 July 2014, Accepted: 2 January 2015

\section{INTISARI}

\begin{abstract}
Penelitian ini bertujuan untuk mengkaji pengaruh pemberian jagung kuning fermentasi dengan suplementasi minyak ikan (tuna dan lemuru) sebagai sumber polyunsaturated fatty acid, dan L-karnitin terhadap daya tetas telur burung puyuh (Coturnix coturnix japonica). Penelitian menggunakan 160 ekor puyuh betina dan 40 ekor puyuh jantan berumur 70 hari. Desain penelitian menggunakan Rancangan Acak Lengkap (RAL) dengan lima perlakuan dan empat ulangan, setiap ulangan berisi delapan ekor puyuh betina dan dua ekor puyuh jantan. Perlakuan yang diuji yaitu $\mathrm{P} 0=$ ransum basal, $\mathrm{P} 1=$ ransum $\mathrm{P} 0$ dengan substitusi $100 \%$ jagung kuning terfermentasi, $P 2=$ ransum $P 1+L$-karnitin 10 ppm, $P 3=$ ransum P3+ minyak ikan tuna 4\%, dan P4= ransum P2+ minyak ikan lemuru 4\%. Ransum menggunakan jagung kuning fermentasi baik tanpa maupun dengan suplementasi sumber polyunsaturated fatty acid dan $L$ karnitin tidak berpengaruh terhadap fertilitas, daya tetas, dan kualitas tetas, namun berpengaruh sangat nyata $(P<0,01)$ terhadap bobot tetas. Perlakuan yang memberikan hasil paling baik ialah $P 1$ karena terdapat jagung kuning fermentasi yang meningkatkan bobot tetas. Kesimpulan penelitian yaitu pemberian jagung kuning fermentasi tanpa maupun dengan suplementasi minyak ikan sebagai sumber polyunsaturated fatty acid dan L-karnitin, belum mampu meningkatkan fertilitas, daya tetas, dan kualitas tetas telur burung puyuh, namun dapat meningkatkan bobot tetas day old quail (DOQ).
\end{abstract}

(Kata kunci: Daya tetas, Jagung kuning terfermentasi, L-karnitin, Puyuh, Polyunsaturated fatty acid)

\section{ABSTRACT}

The aim of the research was to evaluate the effect of feeding fermented yellow corn with polyunsaturated fatty acid and L-Karnitin supplementation on the hatchability of quail (Coturnix-coturnix japonica) egg. A number of 160 female and 40 male quails of 70 days old were used as experimental animal. The present research was designed in oneway Completely Randomized Design (CRD) with five treatments and four replication, each replication contains of eight female and two males quails. The dietary treatments were $P 0=$ basal diet, $P 1=P 0$ with $100 \%$ substitution at yellow corn by fermented yellow corn, $P 2=P 1+10$ ppm L-karnitin, $P 3=P 2+4 \%$ tuna fish oil, $P 4=P 2+4 \%$ lemuru fish oil. Suplementation of fish oil as polyunsaturated fatty acid source and L-karnitin in fermented yellow corn diet didn't affect eggs fertility, hatchability, and hatching quality, however, it significantly $(P<0.01)$ affected hatching weight. The best result achieved in treatment $P 1$ because it content yellow corn fermentation which increased the weight of hatching. It can be concluded that feeding fermented yellow corn with supplementation of polyunsaturated fatty acid source and L-karnitin quail eggs, increase DOQ hatching weight of quail eggs.

(Key words: Fermented yellow corn, Hatchability, L-karnitin, Polyunsaturated fatty acid, Quail)

\section{Pendahuluan}

Pola pemeliharaan burung puyuh biasanya masih mengandalkan day old quail (DOQ) yang berasal dari peternakan rakyat. Pengusaha penetasan hingga kini belum

* Korespondensi (corresponding author):

Telp. +62 85749044331

E-mail: ayu.siswoyo@yahoo.com banyak yang dapat menghasilkan DOQ sesuai dengan permintaan konsumen, baik permintaan dalam hal kualitas dan kuantitas, sehingga perlu adanya usaha untuk meningkatkan daya tetas terhadap telur burung puyuh.

Upaya peningkatan daya tetas burung puyuh dapat dilakukan dengan pemberian ransum yang berkualitas baik, disertai 
pemberian feed additive. Minyak ikan merupakan sumber energi yang ekonomis dalam ransum unggas (Olgun dan Yıldız, 2014). Testosteron merupakan hormon yang berperan dalam perkembangan seksual pada individu jantan, terutama dalam proses spermatogenesis, dan memperpanjang daya hidup spermatozoa di dalam epididimis (Murakami et al., 2014; Mao et al., 2007). Asam lemak polyunsaturated fatty acid (PUFA) yang berasal dari ikan tuna dan ikan lemuru terutama docosahexaenoic acid/C22:6n-3 (DHA) berfungsi untuk meningkatkan terjadinya pembentukan prostaglandin pada saluran reproduksi ternak betina, dan lebih lanjut dapat meningkatkan kualitas ovum (Sudibya, 2012). Prostaglandin pada ternak betina berfungsi melisiskan corpus luteum sehingga produksi progesteron menurun. Penurunan produksi progesteron merangsang hipofisa untuk membuka blok Gnrh, jika blok Gnrh terbuka maka produksi folicle stimulating hormone $(\mathrm{FSH})$ dan luteinizing hormone (LH) meningkat sehingga dapat memicu terjadinya perkawinan.

Pemberian asam lemak PUFA menjadi efektif bila disertai dengan penambahan $L$ karnitin sebagai pemacu metabolisme energi di tingkat sel. Pemberian $L$-karnitin bersama asam lemak PUFA sangat dibutuhkan karena dapat membantu metabolisme asam lemak khususnya pengangkutan asam lemak rantai panjang dari sitosol melintasi membran mitokondria bagian dalam, sehingga bermanfaat untuk metabolisme energi (EFSA, 2012). Penggunaan $L$-karnitin secara aman disarankan pada ternak berkisar $10-50 \mathrm{ppm}$ (EFSA, 2012). Penambahan L-karnitin dapat meningkatkan metabolisme asam lemak PUFA, sehingga dapat dimanfaatkan dengan baik.

Burung puyuh sangat membutuhkan energi dan nutrien yang cukup dalam pakan untuk kebutuhan hidup, pertumbuhan, dan juga reproduksi, sehingga perlu adanya pemberian pakan sumber energi. Salah satunya adalah jagung kuning yang berperan sebagai sumber energi dalam ransum unggas (Olgun dan Yıldız, 2014). Kecukupan nutrien akan mempengaruhi produksi telur burung puyuh, sehingga telur yang dihasilkan akan memiliki berat ideal. Bobot rerata telur burung puyuh adalah 10-15 g per butir (Listiyowati dan Roospitasari, 2009). Bobot telur yang baik akan menghasilkan DOQ dengan kualitas atau bobot yang baik.

\section{Materi dan Metode}

\section{Materi}

Penelitian dilaksanakan di desa Gledeg, Kecamatan Karanganom, Kabupaten Klaten dari bulan Oktober sampai November 2013. Puyuh strain Coturnix coturnix japonica fase produksi umur 70 hari sebanyak 160 ekor betina dan 40 ekor jantan dengan berat awal 156,60 $\pm 9,61$ g digunakan dalam penelitian ini. Perbandingan jantan dan betina dalam satu kelompok perkawinan adalah 1:4 (Marsudi dan Saparinto, 2012).

Penelitian ini menggunakan 20 unit kandang baterai yang terbuat dari kawat dan kayu berukuran $60 \times 50 \times 30 \mathrm{~cm}$. Tempat pakan terbuat dari kayu yang telah dilubangi yang berdiameter kurang lebih $1 \mathrm{~cm}$ dan tempat minum terbuat dari plastik, masing-masing berjumlah 20 buah yang ditempatkan pada setiap unit kandang masing-masing 1 buah. Peralatan lain yang digunakan adalah higrometer, timbangan, lampu, mesin tetas manual kapasitas 1000 butir telur, nampan plastik, dan sprayer.

Ransum yang diberikan pada burung puyuh jantan dan betina adalah ransum basal yang terdiri dari bekatul, konsentrat, dan jagung kuning. Ransum perlakuan terdiri dari bekatul, konsentrat, jagung kuning fermentasi, minyak ikan tuna, minyak ikan lemuru, dan $L$-karnitin dengan komposisi dan kandungan nutrien seperti tersaji pada Tabel 1.

\section{Pelaksanaan penelitian}

Tahap adaptasi dilakukan selama 7 hari. Pemberian ransum pada tahap adaptasi menggunakan ransum puyuh komersial fase layer yang dicampur dengan ransum perlakuan menjadi satu secara bertahap. Hari pertama dengan perbandingan ransum puyuh komersial dan ransum perlakuan yaitu 80:20. Hari kedua 70:30, hari ketiga 60:40, hari keempat dengan perbandingan 50:50, hari kelima 40:60, hari keenam 30:70 dan hari ketujuh 20:80. Hingga tahap perlakuan dimulai yaitu hari kedelapan persentase ransum perlakuan menjadi $100 \%$. Tahap perlakuan dimulai saat puyuh berumur 78 hari. Pemberian air minum secara ad libitum dan pemberian ransum sebanyak 1 kali per hari pada pagi hari. Perlakuan dilakukan 
selama satu bulan sehingga koleksi telur dilakukan ketika masa perlakuan mencapai satu bulan atau pada saat puyuh berumur 108 hari.

Tahap penetasan telur dimulai dengan pengumpulan dan seleksi telur sesuai dengan perlakuan. Telur dibersihkan dari kotoran yang menempel dengan alkohol $70 \%$, diberi label sesuai dengan perlakuan dan ulangan, serta diidentifikasi kondisi, warna, dan bentuk. Persiapan mesin tetas yang dilakukan adalah pembersihan mesin tetas dari sisa penetasan sebelumnya, pengisian air pada nampan plastik yang diletakkan di bawah rak penetasan untuk pengaturan kelembaban. kelembaban mesin tetas diatur antara $60-70 \%$, sedangkan suhu mesin tetas diatur pada $37,5^{\circ} \mathrm{C}$.

\section{Metode}

Penelitian ini dilakukan secara eksperimental menggunakan Rancangan Acak Lengkap (RAL) dengan lima perlakuan yaitu: $\mathrm{P} 0=$ ransum basal, $\mathrm{P} 1=$ ransum basal $+100 \%$ jagung kuning terfermentasi untuk substitusi jagung kuning dalam ransum basal, $\mathrm{P} 2=$ ransum $\mathrm{P}_{1}+L$-karnitin $10 \mathrm{ppm}$, $\mathrm{P} 3=$ ransum $\mathrm{P}_{2}+$ minyak ikan tuna $4 \%$, dan $\mathrm{P} 4=$ ransum $\mathrm{P}_{2}+$ minyak ikan lemuru $4 \%$.

Parameter yang diamati yaitu fertilitas, daya tetas, kualitas tetas, dan bobot tetas. Fertilitas merupakan persentase jumlah telur yang fertil dari jumlah telur keseluruhan yang ditetaskan. Daya tetas merupakan persentase jumlah telur yang menetas dari jumlah telur fertil yang ditetaskan. Kualitas tetas yaitu persentase jumlah telur yang menetas dari jumlah keseluruhan telur yang ditetaskan. Bobot tetas merupakan bobot DOQ setelah menetas yang bulu badannya telah kering sebelum diberi makan dan minum.

\section{Analisis statistik}

Data dianalisis menggunakan analisis variansi untuk mengetahui adanya pengaruh terhadap peubah yang diamati. Apabila hasil analisis data yang ditemukan adanya pengaruh dilanjutkan dengan uji jarak berganda Duncan's (Duncan's Multiple Range Test/DMRT) untuk mengetahui perbedaan antar perlakuan (Aygun et al., 2012).

Tabel 1. Susunan ransum penelitian dan kandungan nutrien (experimental ration composition and nutrition content)

\begin{tabular}{lccccc}
\hline \hline \multicolumn{1}{c}{ Bahan ransum (ration ingredients) } & $\mathrm{P} 0(\%)$ & $\mathrm{P} 1(\%)$ & $\mathrm{P} 2(\%)$ & $\mathrm{P} 3(\%)$ & $\mathrm{P} 4(\%)$ \\
\hline Bekatul (rice bran) & 40,000 & 40,000 & 40,000 & 40,000 & 40,000 \\
Jagung kuning (yellow corn) & 32,000 & 0 & 0 & 0 & 0 \\
Jagung kuning terfermentasi & 0 & 32,000 & 32,000 & 32,000 & 32,000 \\
(fermented yellow corn) & & & & & 28,000 \\
Konsentrat ayam petelur (concentrate) & 28,000 & 28,000 & 28,000 & 28,000 & 0,001 \\
L-karnitin (L-carnitine) & 0 & 0 & 0,001 & 0,001 & 0 \\
Minyak ikan tuna (tuna fish oil) & 0 & 0 & 0 & 4,000 & 4,000 \\
Minyak ikan lemuru (lemuru fish oil) & 0 & 0 & 0 & 0 & 104,001 \\
\hline$\quad$ Jumlah & 100,000 & 100,000 & 100,001 & 104,001 & $3.128,72$ \\
\hline Kandungan nutrien (nutrition content) & $2.749,52$ & $2.797,52$ & $2.797,52$ & $3.127,92$ & 17,78 \\
$\quad$ Energi metabolis (kcal/kg) & 17,14 & 17,78 & 17,78 & 17,78 & 7,20 \\
(metabolizable energy) & 6,96 & 6,96 & 6,96 & 7,19 & 4,41 \\
Protein kasar (\%) (crude protein) & 5,02 & 4,50 & 4,38 & 4,41 & 3,40 \\
Lemak kasar (\%) (ether extract) & 3,39 & 3,40 & 3,40 & 3,40 & 0,53 \\
Serat kasar (\%) (crude fiber) & 0,53 & 0,53 & 0,53 & 0,53 & 10,08 \\
Ca (\%) & 10,08 & 10,08 & 10,08 & 10,08 & 13,42 \\
P tersedia (\%) (available P) & 13,42 & 13,42 & 13,42 & 13,42 & \\
Air (\%) (water) & & & & & \\
Abu (\%) (ash) & & & & & \\
\hline
\end{tabular}

P0: Ransum basal (basal ration)

$\mathrm{P} 1: \mathrm{P}_{0}+100$ persen jagung kuning fermentasi untuk substitusi jagung kuning dalam ransum basal $\left(P_{0}+100\right.$ percent basal ration of fermented yellow corn to substitute yellow corn in basal ration).

$\mathrm{P} 2$ : Ransum $\mathrm{P}_{1}+L$-karnitin $10 \mathrm{ppm}\left(P_{1}\right.$ ration $+10 \mathrm{ppm}$ of $L$-carnitine $)$

P3: Ransum $\mathrm{P}_{2}+$ minyak ikan tuna 4 persen $\left(P_{3}=P_{2}\right.$ ration +4 percent of tuna fish oil).

P4: Ransum $\mathrm{P}_{2}+$ minyak ikan lemuru 4 persen $\left(P_{2}\right.$ ration +4 percent of lemuru fish oil). 


\section{Hasil dan Pembahasan}

\section{Fertilitas}

Hasil analisis variansi me-nunjukkan bahwa substitusi jagung kuning fermentasi dalam ransum dengan suplementasi PUFA dan $L$-karnitin berpengaruh tidak nyata terhadap fertilitas telur burung puyuh (Tabel 3). Pemberian substitusi jagung kuning fermentasi, suplementasi PUFA dan Lkarnitin dalam ransum belum dapat meningkatkan fertilitas telur burung puyuh. Hal ini menunjukkan bahwa energi yang dihasilkan oleh jagung kuning fermentasi, PUFA dan L-karnitin sama. Salah satu penentu fertilitas adalah motilitas sperma atau pergerakan sperma. Adipu et al. (2011) menyatakan bahwa sperma memerlukan energi karena dalam proses fertilisasi sperma menggunakannya untuk bergerak menuju ovum sehingga dapat membuahi ovum. Hal ini dimungkinkan pengaturan energi untuk motilitas sperma dipengaruhi oleh kandungan laktosa dalam cairan sperma. Metabolisme pembentukan laktosa tersebut diatur oleh hormon insulin yang mempunyai mekanisme homeostatis (Ferry, 2008), sehingga pada kondisi minimal tersedia prekursor energi sudah cukup untuk membentuk laktosa pada cairan sperma.

PUFA yang berasal dari minyak ikan terutamanya DHA di dalam tubuh burung puyuh dapat membantu hormon reproduksi untuk menjalankan fungsinya. Hormon reproduksi seperti testosteron dalam proses spermatogenesis dan prostaglandin pada ternak betina (Sudibya, 2012; Mao et al., 2007). Hormonal di dalam tubuh ternak bersifat homeostatis yang berarti jika kebutuhan telah terpenuhi maka akan terjadi keadaan yang sama dengan kata lain tidak berubah atau tetap (Hernawati, 2000). Penambahan PUFA didalam ransum tidak memberikan pengaruh terhadap fertilitasnya. $L$-karnitin tidak memberikan pengaruh terhadap fertilitas karena fungsi dari Lkarnitin untuk membantu metabolisme lemak di dalam sel, sehingga tidak memberikan pengaruh terhadap fertilitas. Sesuai dengan pernyataan EFSA (2012), yang menyatakan

Tabel 2. Desain pengambilan telur (jumlah telur/butir) (design of egg collection (total egg/grain))

\begin{tabular}{|c|c|c|c|c|c|c|}
\hline \multirow[t]{2}{*}{ Pengambilan (taking) } & \multirow{2}{*}{$\begin{array}{c}\text { Perlakuan } \\
\text { (treatments) }\end{array}$} & \multicolumn{4}{|c|}{ Ulangan (repetition) } & \multirow[t]{2}{*}{ Tota } \\
\hline & & U1 & U2 & U3 & U4 & \\
\hline Minggu I (first week) & $\mathrm{P} 0$ & 9 & 9 & 9 & 9 & 36 \\
\hline Hari ke-1, 2, 3 (days & $\mathrm{P} 1$ & 9 & 9 & 9 & 9 & 36 \\
\hline \multirow[t]{3}{*}{ of $1,2,3)$} & $\mathrm{P} 2$ & 9 & 9 & 9 & 9 & 36 \\
\hline & P3 & 9 & 9 & 9 & 9 & 36 \\
\hline & P4 & 9 & 9 & 9 & 9 & 36 \\
\hline \multicolumn{6}{|c|}{ Jumlah telur pada penetasan 1 (egg number at first hatchery) } & 180 \\
\hline Minggu I (first week) & $\mathrm{PO}$ & 9 & 9 & 9 & 9 & 36 \\
\hline Hari ke-4, 5, 6 (days & P1 & 9 & 9 & 9 & 9 & 36 \\
\hline \multirow[t]{3}{*}{ of $4,5,6)$} & $\mathrm{P} 2$ & 9 & 9 & 9 & 9 & 36 \\
\hline & P3 & 9 & 9 & 9 & 9 & 36 \\
\hline & $\mathrm{P} 4$ & 9 & 9 & 9 & 9 & 36 \\
\hline \multicolumn{6}{|c|}{ Jumlah telur pada penetasan 2 (egg number at second hatchery) } & 180 \\
\hline $\begin{array}{l}\text { Minggu II (second } \\
\text { week) }\end{array}$ & P0 & 9 & 9 & 9 & 9 & 36 \\
\hline Hari ke-1, 2, 3 (days & P1 & 9 & 9 & 9 & 9 & 36 \\
\hline \multirow[t]{3}{*}{ of $1,2,3)$} & P2 & 9 & 9 & 9 & 9 & 36 \\
\hline & P3 & 9 & 9 & 9 & 9 & 36 \\
\hline & $\mathrm{P} 4$ & 9 & 9 & 9 & 9 & 36 \\
\hline \multicolumn{6}{|c|}{ Jumlah telur pada penetasan 3 (egg number at third hatchery) } & 180 \\
\hline $\begin{array}{l}\text { Minggu II (second } \\
\text { week) }\end{array}$ & $\mathrm{PO}$ & 9 & 9 & 9 & 9 & 36 \\
\hline Hari ke-4, 5, 6 (days & P1 & 9 & 9 & 9 & 9 & 36 \\
\hline \multirow{3}{*}{ of $4,5,6)$} & $\mathrm{P} 2$ & 9 & 9 & 9 & 9 & 36 \\
\hline & P3 & 9 & 9 & 9 & 9 & 36 \\
\hline & $\mathrm{P} 4$ & 9 & 9 & 9 & 9 & 36 \\
\hline \multicolumn{6}{|c|}{ Jumlah telur pada penetasan 4 (egg number at fourth hatchery) } & 180 \\
\hline \multicolumn{6}{|c|}{ Total seluruh telur yang ditetaskan (total number of hatched eggs) } & 720 \\
\hline
\end{tabular}


bahwa peran penting dari L-karnitin adalah metabolisme asam lemak dan sebagai pengangkutan asam lemak rantai panjang untuk melintasi membran mitokondria dalam pembentukkan energi sel.

\section{Daya tetas}

Hasil analisis variansi menunjukkan bahwa substitusi jagung kuning fermentasi dalam ransum dengan suplementasi PUFA dan L-karnitin berpengaruh tidak nyata terhadap daya tetas telur burung puyuh (Tabel 3). Subtitusi jagung kuning fermentasi dalam ransum dengan suplementasi PUFA dan $L$-karnitin belum dapat meningkatkan nilai daya tetas. Daya tetas merupakan persentase jumlah telur yang menetas dari jumlah telur yang fertil (Aygun dan Sert, 2013). Purnama (2014) menyatakan bahwa daya tetas dipengaruhi oleh fertilitas telur yang akan ditetaskan, fertilitas yang baik akan memberikan daya tetas yang tinggi begitu sebaliknya bahwa fertilitas yang rendah akan menghasilkan daya tetas yang rendah. Nuryati et al. (2000) menyatakan bahwa telur yang dapat menetas adalah telur yang dalam keadaan fertil. Fertilitas telur didapatkan jika telur telah dibuahi oleh sperma. Pernyataan tersebut berkaitan dengan hasil yang didapatkan dalam penelitian ini bahwa fertilitas yang dihasilkan dalam penelitian ini tidak berpengaruh nyata, sehingga menyebabkan daya tetasnya juga tidak berpengaruh nyata.

\section{Kualitas tetas}

Hasil analisis variansi menunjukkan bahwa substitusi jagung kuning fermentasi dalam ransum dengan suplementasi PUFA dan L-karnitin berpengaruh tidak nyata terhadap kualitas tetas telur burung puyuh (Tabel 3). Subtitusi jagung kuning fermentasi dalam ransum dengan suplementasi PUFA dan L-karnitin belum dapat meningkatkan nilai kualitas tetas.

Kualitas tetas didapat dari perbandingan antara jumlah telur yang menetas dengan jumlah telur yang masuk (baik fertil maupun infertil) (Aygun dan Sert, 2013). Damayanti (2013) menjelaskan bahwa, kualitas tetas dalam penetasan dapat dipengaruhi oleh daya tetas. Pernyataan tersebut berkaitan dengan hasil yang didapatkan dalam penelitian ini bahwa daya tetas yang dihasilkan dalam penelitian ini tidak berpengaruh nyata, sehingga menyebabkan kualitas tetas juga tidak berpengaruh nyata.

\section{Bobot tetas}

Hasil analisis variansi menunjukkan bahwa substitusi jagung kuning fermentasi dalam ransum dengan suplementasi PUFA dan $L$-karnitin berpengaruh sangat nyata $(P<0,01)$ terhadap bobot tetas (Tabel 3$)$. Berdasarkan uji lanjut diperoleh hasil $P 0$ berbeda sangat nyata dengan P1, P2, P3, P4, tetapi P1, P2, P3, P4 memberikan hasil berbeda tidak nyata. Rerata bobot tetas semakin tinggi dengan perlakuan suplementasi jagung kuning fermentasi dibandingkan dengan kontrol.

Fermentasi jagung kuning bertujuan untuk meningkatkan kandungan nutrien jagung, palatabilitas dan nilai kecernaannya sehingga dapat mempengaruhi bobot tetas. Hal ini sesuai dengan pernyataan Wallace dan Newbold (1996) bahwa tujuan awal fermentasi untuk meningkatkan nilai kecernaan, sehingga penyerapan nilai nutrien pada ransum lebih optimal, yang pada akhirnya produktivitas akan meningkat. Peningkatan nutrien diimbangi dengan peningkatan asam amino yang terkandung

Tabel 3. Pengaruh jagung kuning fermentasi dalam ransum dengan suplementasi polyunsaturated fatty acid (PUFA) dan L-karnitin terhadap daya tetas telur burung puyuh

(the effect of fermented yelow corn in the diet with polyunsaturated fatty acid (PUFA) and L-carnitine supplementation on the hatchability of quail egg)

\begin{tabular}{|c|c|c|c|c|c|c|}
\hline \multirow[t]{2}{*}{ Variabel (variable) } & \multicolumn{5}{|c|}{ Perlakuan (treatments) } & \multirow{2}{*}{$\operatorname{Pr}>F^{*}$} \\
\hline & $\mathrm{P} 0$ & P1 & P2 & P3 & P4 & \\
\hline Fertilitas (\%) (fertility) & 41,66 & 41,66 & 54,16 & 54,86 & 59,03 & $0,5023^{\text {ns }}$ \\
\hline Daya tetas (\%) (hatchability) & 57,59 & 71,16 & 66,97 & 66,50 & 83,94 & $0,8100^{\text {ns }}$ \\
\hline Kualitas tetas (\%) (hatching quality) & 24,28 & 39,58 & 36,80 & 50,69 & 51,39 & $0.2195^{\mathrm{ns}}$ \\
\hline Bobot tetas $(\mathrm{g})$ (hatching weight) & $5,63^{b}$ & $6,91^{\mathrm{a}}$ & $6,88^{a}$ & $6,54^{a}$ & $6,91^{a}$ & $0.0004^{* *}$ \\
\hline
\end{tabular}


dalam jagung kuning fermentasi. Peningkatan tersebut digunakan sebagai pemenuhan kebutuhan pertumbuhan embrio dalam telur sehingga akan memperbaiki bobot tetas yang dihasilkan. Asam amino yang terkandung didalam jagung kuning fermentasi lebih tinggi dibandingkan dengan jagung kuning yang tidak difermentasi sehingga digunakan untuk pertumbuhan embrio di dalam telur. Luna et al. (2012) menyatakan bahwa proses fermentasi dapat meningkatkan lisin. Terpenuhinya nutrien yang dibutuhkan maka akan memperbaiki bobot tetas telur burung puyuh.

\section{Kesimpulan}

Berdasarkan hasil penelitian dapat disimpulkan bahwa pemberian jagung terfermentasi baik dengan maupun tanpa suplementasi minyak ikan sebagai sumber polyunsaturated fatty acid, dan L-karnitin dapat meningkatkan bobot tetas anak burung, tetapi menghasilkan fertilitas, daya tetas, dan kualitas tetas yang sama.

\section{Daftar Pustaka}

Adipu, Y., H. Sinjal, dan J. Watung. 2011. Ratio pengenceran sperma terhadap motilitas spermatozoa, fertilitas dan daya tetas ikan lele (Clarias $s p$ ). Jurnal Perikanan dan Kelautan Tropis 7: 1-8.

Aygun, A. dan D. Sert. 2013. Effects of prestorage application of propolis and storage time on eggshell microbial activity, hatchability, and chick performance in Japanese quail eggs. Poult Sci. 12: 3330-3337.

Aygun, A., D. Sert, and G. Copur. 2012. Effects of propolis on eggshell microbial activity, hatchability, and chick performance in Japanese quail eggs. Poult. Sci. 4: 1018-1025.

Damayanti, M. 2013. Pengaruh umur dan bobot telur itik lokal terhadap mortalitas, kualitas tetas dan bobot tetas. Skripsi Fakultas Pertanian, Universitas Sebelas Maret, Surakarta.

EFSA (European Food Safety Authority). 2012. Scientific Opinion on the safety and efficacy of L-carnitine as a feed additive for all animal species based on a dossier submitted by EUROPEASIA Import Export GmbH. EFSA, Parma.
Ferry, R. J. 2008. Fructose 1,6Diphosphatase Deficiency. http//emedicene. Medscape.com// article/943882-overview. Accessed 8 October 2014.

Hernawati. 2000. Mineral dan Homeostatis. Jurusan Pendidikan Biologi. Fakultas MIPA, Universitas Pendidikan Indonesia, Bandung.

Listiyowati, E. dan K. Roospitasari. 2009. Beternak Puyuh secara Komersial. Penebar Swadaya, Jakarta.

Luna, A., J. S. Dambolena, J. A. Zygadlo, R. H. Marin and M. C. Labaque. 2012. Effects of thymol and isoeugenol feed supplementation on quail adult performance, egg characteristics and hatching success. Br. Poult. Sci. 5: 631-639.

Marsudi dan C. Saparinto. 2012. Puyuh. Penebar Swadaya, Jakarta.

Mao, K. M., A. Murakami, A. Iwasawa and N. Yoshizaki. 2007. The asymmetry of avian egg-shape: an adaptation for reproduction on dry land. J. Anat. 6: 741-748.

Murakami, A. E., R. J. Rodrigueiro, T. C. Santos, I. C. Ospina-Rojas and M. Rademacher. 2014. Effects of dietary supplementation of meat-type quail breeders with guanidinoacetic acid on their reproductive parameters and progeny performance. Poult. Sci. 9: 2237-2244.

Nuryati, L., K. Sutarto, dan S. P. Hardjosworo. 2000. Sukses Menetaskan Telur. Penebar Swadaya, Jakarta.

Olgun, O. and A. Ö. Yıldız. 2014. Effect of dietary supplementation of essential oils mixture on performance, eggshell quality, hatchability, and mineral excretion in quail breeders. Environ Sci. Poult. Res. Int. 23: 13434-13439.

Purnama, Y. W., I. H. Djunaidi, dan E. Sudjarwo. 2014. Pengaruh penambahan tepung kulit manggis (Garcinia mangostana L.) dalam pakan terhadap tingkat fertilitas, daya tetas, dan bobot tetas itik Mojosari. Skripsi Fakultas Peternakan, Universitas Brawijaya, Malang.

Sudibya. 2012. Buku Ajar Biokimia. Fakultas Pertanian, Universitas Sebelas Maret, Surakarta. 
Wallace, R. J. and W. Newbold. 1996. Mode of action of the yeast Saccharomyces cerevisiae as a feed additive for ruminants. Br. J. Nutr. 76: 249-261. 